\title{
Ginger Mitigates Total Sleep Deprivation Adverse Effects: A Curative Effect of Recovery Sleep
}

\author{
Ahmed M Shehata \\ Physiology Department- National Organization for Drug Control and \\ Research, Egypt
}

\begin{abstract}
The present study aimed to explore the biochemical, hematological and histological effects of sleep deprivation and effect of aqueous extract of ginger and recovery sleep in rats. Adult male rats were sleep deprived for a period of 5 days using grid suspended over water method. Aqueous ginger extract (500 mg/kg/day, p.o) was administered for 8 days, starting 3 days before sleep deprivation. Recovery sleep was allowed for two days. Sleep deprivation insignificantly increased corticosterone, significantly elevated levels of malondialdehyde and protein carbonyls, decreased levels of ascorbic acid, reduced glutathione (GSH) and depressed total antioxidant activity in blood plasma and heart. In addition, sleep deprivation increased level of total IgGs, elevated total count of leucocytes and differential (neutrophils and lymphocytes). Besides, sleep deprivation caused extravasations of Evan's blue dye in the brain tissues (brain cortex, midbrain and brain stem). Moreover, sleep deprivation induced histological abnormalities in cardiac tissue manifested as inflammation, hemorrhage and degeneration of cardiomyocytes. Ginger extract significantly offered protection against the harmful effects of sleep deprivation. Recovery sleep had a restorative effect of the normal levels of most tested parameters. The study indicated that sleep deprivation caused harmful effects independent of stress earnings, by inducing oxidative stress and inflammatory reaction leading to damage in the cardiac tissue and temporally breakdown in the blood brain barrier. It's worthy to note that ginger offered protection while recovery sleep had a restorative effect against sleep deprivation effects.
\end{abstract}

Keywords: Sleep deprivation, ginger, recovery sleep, blood, heart, brain.

\section{INTRODUCTION}

Sleep is important for the maintenance of physiological homeostasis and psychological balance. Disturbance or shortening of normal sleep is associated with an irregularity of the neuroendocrine control of appetite and increased risk of diabetes ${ }^{(1,2)}$. In accordance, sleep deprivation has been reported to disturb many vital processes including gene expression related to metabolic processes, response to stress and inflammation, circadian sleep/wake cycles, regulation of cell proliferation and various signaling pathways ${ }^{(\mathbf{3})}$.

Moreover, sleep deprivation has been reported to increase plasma glucocorticoids in both human and rodents $^{(4)}$, and leads to augmentation of the aging process and gradual damage to brain cells ${ }^{(5)}$. In addition, sleep restriction to four hours for three consecutive nights was found to 
increase leuckocytic count, mainly neutrophils in young healthy men ${ }^{(6)}$. Also, sleep deprivation has been found to elevate parameters of humoral immunity, including serum IgG, IgA, IgM, and cytokines $\mathrm{C} 3$ and C4 (7). Acute total and short-term partial sleep deprivation resulted in elevated high-sensitivity $\mathrm{C}$ - reactive protein (CRP) concentrations, a stable marker of inflammation that has been shown to be predictive of cardiovascular morbidity ${ }^{(8-10)}$. In addition, inflammation has been reported to increase blood brain barrier permeability and to play a central role in the development of numerous disorders of the central nervous system (CNS) ${ }^{(11)}$. Whereas, recovery sleep has been reported to ameliorate the adverse effects of sleep deprivation on physiological process and restore the antioxidant balance ${ }^{\text {(12) }}$

Ginger is an herbal remedy contains very potent antiinflammatory and antioxidant compounds including 6-shogaol, 6gingerol, 8-gingerol and 10gingerol $^{(13,14)}$. These substances are believed to have therapeutic potentials against osteoarthritis or rheumatoid arthritis ${ }^{(15-17)}$. In addition, ginger has been found to suppress_(Th2) - cell mediated immune responses, providing a possible therapeutic application in allergic asthma ${ }^{(18)}$. Moreover, aqueous extract of ginger has showed detoxifying and antioxidant effects against alcohol toxicity ${ }^{(19)}$.

The study aimed to explore the biochemical, hematological and histopathological effects of sleep deprivation and possible protective and restorative effects of ginger and recovery sleep respectively.

\section{MATERIALS \& METHODS}

\section{Animals:}

Sprague Dawley rats $(200 \pm 30 \mathrm{~g})$ were obtained from the animal house of the National Organization for Drug Control and Research (NODCAR), Egypt. The animals were kept under standard laboratory conditions of light/dark cycle $(12 \mathrm{~h} / 12 \mathrm{~h})$ and temperature $\left(25 \pm 2 \mathrm{C}^{\circ}\right)$. They were provided with a nutritionally adequate standard laboratory diet. All experiments were carried out in accordance with institutional guidelines established by the animal care and use committee of the National Organization for Drug Control and Research (NODCAR), Egypt.

All chemicals used were of analytical grade.

Experimental design: A total number of 60 rats were used in the study and divided equally into two sets, one for the biochemical, hematological and histological studies and the other for blood brain barrier study. Each set is divided into five groups,1) control group, where the animals had normal sleep; 2) sleep deprivation (SD) group, the animals sleep deprived for 5 days; 3 ) sleep deprivation and ginger $(S D+G)$ group, the animals were administered ginger (500mg/ kg, p.o, day) for 8 days, starting 3 days before sleep deprivation for 5 days; 4) ginger $(G)$ group, the animals were administered ginger $(500 \mathrm{mg} / \mathrm{kg}$, p.o, day) for 8 days. Recovery sleep (RS) group, the animals were allowed to have normal 
sleep for two days after sleep deprivation for five days.

\section{Sleep deprivation}

Animals were sleep deprived for 5 days by placing them on a grid suspended over water ${ }^{(20)}$. Briefly, they were placed on a grid floor $(29 \times 15 \times 7 \mathrm{~cm})$ inside the plastic cage filled with water to $1 \mathrm{~cm}$ below the grid surface. The stainless steel rods of the grid ( $3 \mathrm{~mm}$ wide) were set $2 \mathrm{~cm}$ apart from each other. Food and water were provided ad libitum. After sleep deprivation session, the animals from different groups were sacrificed; blood was collected in plastic centrifuge tubes containing $0.01 \%$ ethylenediaminetetraacetic acid (EDTA) as anticoagulant and antioxidant. Blood was centrifuged at $4{ }^{\circ} \mathrm{C}$ for $15 \mathrm{~min}$ at $3000 \mathrm{rpm}$ and plasma was stored at $-80^{\circ} \mathrm{C}$ until further processing. The animals were dissected and hearts were obtained.

Determination of total IgGs was determined by SEC- HPLC method using purified mouse IgG (Sigma, St Louis, MO) as reference ${ }^{(21)}$. Determination of reduced glutathione, homocysteine, vitamin $\mathrm{C}$ and malondialdehyde levels were determined by HPLC methods ${ }^{(22-24)}$, respectively. Protein carbonyls were determined according to spectrophotometric method ${ }^{(25)}$. Protein determination was carried out using colorimetric method $^{(26)}$. Erythrocyte sedimentation rate, total and differential leucocytic count were carried out using the method of Simmons and Bernard ${ }^{(27)}$. C- reactive protein was detected with ELISA kit for rats (Genway Biotech, Inc., CA, USA), with the normal level being less than $0.5 \mathrm{mg} / \mathrm{ml}$. To assess the stress effect of sleep deprivation, corticosterone was measured with ELISA kit for rats (Genway Biotech, Inc., CA, USA). Histopathological preparation was carried out according to method of Carleton ad Drury ${ }^{(28)}$.

Blood brain barrier integrity was determined using the method described by Mikawa et al ${ }^{(29)}$ using Evans blue (EB) dye. In brief, after the last session of sleep deprivation, EB dye (4 $\mathrm{ml} / \mathrm{kg}, 2 \%)$ was administered intraperitonealy and allowed to circulate for $60 \mathrm{~min}$. The animals were then anaesthetized with thiopental $(50 \mathrm{mg} / \mathrm{kg}$, ip) and perfused with saline through the left ventricle at a flow rate $10 \mathrm{ml} / \mathrm{min}$ for $15 \mathrm{~min}$. until colorless fluid was obtained from the right atrium. Afterwards, the brains were removed and dissected into brain cortex, midbrain and brain stem. The brain areas were weighed and homogenized in $3.5 \mathrm{ml}$ phosphate-buffered saline and vortexmixed for $2 \mathrm{~min}$ after the addition of $2.5 \mathrm{ml}$ of $60 \%$ trichloroacetic acid to precipitate protein. The samples were then cooled in ace for $30 \mathrm{~min}$ and centrifuged for $30 \mathrm{~min}$ at 1000 r.p.m. The absorbance of the supernatants for EB dye was measured at $610 \mathrm{~nm}$ with a spectrophotometer. EB dye content is expressed as $\mu \mathrm{g} / \mathrm{mg}$ of brain tissue against a standard curve.

\section{Statistical Analysis}

Data presented as means $\pm \mathrm{SE}$. One-way ANOVA followed by LSD test were used to evaluate significant differences from the control and sleep deprived groups. $\quad P<0.05$ was considered to be statistically significant. Statistical processor system support (SPSS) for Windows 
software, release 10.0 (SPSS, Inc, Chicago, IL) was used.

\section{RESULTS}

\section{Oxidative stress parameters:}

Sleep deprivation induced significant decrease in the level of GSH, increased GSSG level and disturbed GSH/GSSG ratio in the heart and blood plasma. Ginger treatment to SD rats maintained the levels of reduced glutathione and the GSH/GSSG ratio around the normal level (Tables $1 \& 2$ ). Recovery sleep was powerful than ginger to maintain the levels of reduced glutathione and the GSH/GSSG ratio around the normal level (Tables 1\&2). Plasma levels of the stress hormone corticosterone in sleep deprived rats insignificantly increased in comparison to control animals (SD: $6.22 \pm 0.58 \mathrm{~g} / \mathrm{dl}$, control: $5.11 \pm 0.65$ $\mathrm{g} / \mathrm{dl}$ ). Minor changes were detected with other treatments (Table 3). Sleep deprivation significantly decreased level of vitamin $\mathrm{C}$ and total antioxidant activity, whereas increased the levels of MDA and protein carbonyls (Tables 3, 4, $5 \& 6$ ). Ginger treatment to SD rats significantly minimized the decreasing effect of SD on vitamin C concentration and total antioxidant activity, and also minimized the increasing effect of SD on MDA and protein carbonyls levels in both the heart and blood plasma (Tables 3, 4, $5, \& 6$ ). Sleep recovery was powerful than ginger in keeping the normal levels of vitamin $\mathrm{C}$ and total antioxidant activity, and prevented the increasing effect of SD on levels of MDA and protein carbonyls in both the heart and blood plasma (Tables 3, $4,5 \& 6)$.

\section{Inflammatory parameters:}

Sleep deprivation induced significant increase in the levels of total and differential leucocytic count, especially in neutophiles, increase ESR and the level of total IgGs, and did not change the level of CRP. Both ginger treatment and recovery sleep significantly minimized the aforementioned effects of sleep deprivation (Tables $7 \& 8$ ).

\section{Blood brain barrier permeability:}

Data in table 8 showed that sleep deprivation induced significant increase in blood brain barrier permeability in the tested brain areas. Both ginger and recovery sleep minimized the effect of sleep deprivation (Table 9).

\section{Histopathology:}

Sleep deprivation for 5 days induced histological abnormalities manifested as hemorrhage, red blood cells aggregates and inflammatory cells within cardiac muscles. In addition, sleep deprived rats showed multi focal areas of degenerated cardiomyocytes with dislocated and pyknotic nuclei (Fig. 3, 4, 5, 6 \&7). Ginger treatment alone (Fig. 8) did not differ from normal cardiac tissue (Fig. 1\&2). Concurrent administration of ginger to sleep deprived rats greatly minimized the adverse effect of sleep deprivation (Fig. 9). Recovery Sleep group showed a remarkable ameliorative effect and minimized the adverse effect of sleep deprivation (Fig. 10). 
Table 1: Effect of Ginger and Recovery Sleep on Levels of Reduced (GSH) and Oxidized (GSSG) Glutathione and Their Ratio in Blood Plasma of Sleep Deprived Rats (SD)

\begin{tabular}{|l|l|l|l|}
\hline \multicolumn{1}{|c|}{ Group } & $\begin{array}{l}\text { GSH } \\
(\mu \mathrm{g} / \mathrm{ml})\end{array}$ & $\begin{array}{l}\text { GSSG } \\
(\mu \mathrm{g} / \mathrm{ml})\end{array}$ & GSH/GSSG \\
\hline Control & $41.191 \pm 1.785$ & $2.815 \pm 0.145$ & $14.736 \pm 0.694$ \\
\hline SD & $32.143 \pm 1.122^{* * *}$ & $4.111 \pm 0.141^{* * *}$ & $7.863 \pm 0.393^{* * *}$ \\
\hline SD + Ginger & $40.119 \pm 1.270^{++}$ & $3.158 \pm 0.185^{+++}$ & $12.925 \pm 0.715^{+++}$ \\
\hline Ginger & $45.120 \pm 2.781^{+++}$ & $3.000 \pm 0.099^{+++}$ & $15.045 \pm 0.798^{+++}$ \\
\hline Recovery Sleep & $42.857 \pm 1.181^{+++}$ & $3.056 \pm 0.103^{+++}$ & $14.112 \pm 0.480^{+++}$ \\
\hline
\end{tabular}

* Significant difference from control, * $(\mathrm{P}<0.05)$ Sign. ** $(\mathrm{P}<0.01)$ High sign.

*** Very high sign.

+ Significant difference from sleep deprived rats, $+(\mathrm{P}<0.05)$ Sign. $++(\mathrm{P}<0.01)$ High sign.

+++ Very high sign

Table 2: Effect of Ginger and Recovery Sleep on Levels of Reduced (GSH) and Oxidized (GSSG) Glutathione and their Ratio in Hearts of Sleep Deprived Rats (SD)

\begin{tabular}{|l|l|l|l|}
\hline \multicolumn{1}{|c|}{ Group } & $\begin{array}{l}\text { GSH } \\
(\mu \mathrm{g} / \mathrm{g} \text { fresh tissue })\end{array}$ & $\begin{array}{l}\text { GSSG } \\
(\mu \mathrm{g} / \mathrm{g} \text { fresh tissue })\end{array}$ & GSH/GSSG \\
\hline Control & $390.441 \pm 19.423$ & $25.029 \pm 1.137$ & $15.658 \pm 0.702$ \\
\hline SD & $264.225 \pm 22.835^{* *}$ & $37.565 \pm 1.067^{* * *}$ & $7.085 \pm 0.667^{* * *}$ \\
\hline SD + Ginger & $359.435 \pm 130738^{+}$ & $28.691 \pm 0.907^{*+++}$ & $12.591 \pm 0.649^{++}$ \\
\hline Ginger & $428.315 \pm 31.572^{+++}$ & $26.709 \pm 0.967^{+++}$ & $16.209 \pm 1.495^{+++}$ \\
\hline Recovery Sleep & $485.368 \pm 52.592^{*++++}$ & $26.322 \pm 1.288^{+++}$ & $18.350 \pm 1.603^{+++}$ \\
\hline
\end{tabular}

* Significant difference from control, $*(\mathrm{P}<0.05)$ Sign. ${ }^{* *}(\mathrm{P}<0.01)$ High sign.

$* * *$ Very high sign.

+ Significant difference from sleep deprived rats, $+(\mathrm{P}<0.05)$ Sign. $++(\mathrm{P}<0.01)$ High sign.

+++ Very high sign

Table 3: Effect of Ginger and Recovery Sleep on Level of Vitamin C, Total Antioxidant

Activity and Corticosterone Level in Blood Plasma of Sleep Deprived Rats (SD)

\begin{tabular}{|c|c|c|c|}
\hline Group & $\begin{array}{l}\text { Vit C } \\
(\mu \mathrm{mol} / 1)\end{array}$ & $\begin{array}{l}\text { Antioxidant activity } \\
\text { (eq. to } \mu \mathrm{g} \text { Vit } \mathrm{C} / \mathrm{ml} \text { ) }\end{array}$ & $\begin{array}{l}\text { Corticosterone } \\
\mu \mathrm{g} / \mathrm{dl}\end{array}$ \\
\hline Control & $51.609 \pm 1.679$ & $57.391 \pm 1.040$ & $5.11 \pm 0.65$ \\
\hline SD & $27.579 \pm 1.367^{* * *,+++}$ & $24.928 \pm 1.259^{* * *}$ & $6.22 \pm 0.58$ \\
\hline SD + Ginger & $65.521 \pm 3.151^{* *,+++}$ & $54.783 \pm 2.449^{+++}$ & $4.92 \pm 0.71$ \\
\hline Ginger & $77.789 \pm 5.535^{* * *,+++}$ & $59.710 \pm 2.744^{+++}$ & $5.52 \pm 0.35$ \\
\hline Recovery Sleep & $58.038 \pm 3.371^{+++}$ & $50.377 \pm 0.854^{*,+++}$ & $5.48 \pm 0.80$ \\
\hline
\end{tabular}

* Significant difference from control, $*(\mathrm{P}<0.05)$ Sign. ** $(\mathrm{P}<0.01)$ High sign.

*** Very high sign.

+ Significant difference from sleep deprived rats, $+(\mathrm{P}<0.05)$ Sign. $++(\mathrm{P}<0.01)$ High sign.

+++ Very high sign 
Table 4: Effect of Ginger and Recovery Sleep on Level of Vitamin C and Total Antioxidant Activity in Heart of Sleep Deprived Rats (SD)

\begin{tabular}{|l|l|l|}
\hline \multicolumn{1}{|c|}{ Group } & $\begin{array}{l}\text { Vit C } \\
(\mu \mathrm{mol} / \mathrm{g} \text { fresh tissue })\end{array}$ & $\begin{array}{l}\text { Antioxidant activity } \\
(\text { Eq. to } \mu \mathrm{g} \text { Vit C/g fresh tissue) }\end{array}$ \\
\hline Control & $28.640 \pm 1.708$ & $248.480 \pm 13.131$ \\
\hline SD & $17.400 \pm 0.432^{* * *}$ & $189.888 \pm 3.638^{* * *}$ \\
\hline SD + Ginger & $27.200 \pm 1.323^{+++}$ & $239.363 \pm 7.308^{++}$ \\
\hline Ginger & $33.600 \pm 2.328^{*++++}$ & $285.733 \pm 12.707^{*+++}$ \\
\hline Recovery Sleep & $20.960 \pm 0.381^{* * *+++}$ & $257.723 \pm 11.754^{+++}$ \\
\hline
\end{tabular}

* Significant difference from control, * $(\mathrm{P}<0.05)$ Sign. $* *(\mathrm{P}<0.01)$ High sign.

*** Very high sign.

+ Significant difference from sleep deprived rats, $+(\mathrm{P}<0.05)$ Sign. $++(\mathrm{P}<0.01)$ High sign.

+++ Very high sign

Table 5: Effect of Ginger and Recovery Sleep on Levels of Protein Carbonyls and Malondialdehyde in Blood Plasma of Sleep Deprived Rats (SD)

\begin{tabular}{|l|l|l|}
\hline \multicolumn{1}{|c|}{ Group } & \multicolumn{1}{|c|}{$\begin{array}{c}\text { Protein Carbonyls } \\
(\text { nmol/mg protein })\end{array}$} & \multicolumn{1}{c|}{$\begin{array}{c}\text { Malondialdehyde } \\
(\mu \mathrm{mol} / \mathrm{l})\end{array}$} \\
\hline Control & $2.833 \pm 0.169^{* *}$ & $1.522 \pm 0.033$ \\
\hline SD & $3.985 \pm 0.095^{* * *}$ & $2.693 \pm 0.120^{* *}$ \\
\hline SD + Ginger & $2.933 \pm 0.092^{+++}$ & $1.945 \pm 0.052^{* * *+++}$ \\
\hline Ginger & $2.817 \pm 0.079^{+++}$ & $1.482 \pm 0.067^{+++}$ \\
\hline Recovery Sleep & $2.917 \pm 0.111^{+++}$ & $1.577 \pm 0.056^{+++}$ \\
\hline
\end{tabular}

* Significant difference from control, * $(\mathrm{P}<0.05)$ Sign. ** $(\mathrm{P}<0.01)$ High sign.

*** Very high sign.

+ Significant difference from sleep deprived rats, $+(\mathrm{P}<0.05)$ Sign. $++(\mathrm{P}<0.01)$ High sign.

+++ Very high sign

Table 6: Effect of Ginger and Recovery Sleep on Levels of Protein Carbonyls and Malondialdehyde in Heart of Sleep Deprived Rats (SD)

\begin{tabular}{|l|l|l|}
\hline \multicolumn{1}{|c|}{ Group } & $\begin{array}{l}\text { Protein Carbonyls } \\
(\mathrm{nmol} / \mathrm{mg} \text { protein })\end{array}$ & $\begin{array}{l}\text { Malondialdehyde } \\
(\mu \mathrm{mol} / \mathrm{g} \text { fresh tissue })\end{array}$ \\
\hline Control & $4.200 \pm 0.281^{* * *}$ & $6.225 \pm 0.232$ \\
\hline SD & $6.230 \pm 0.211^{+* *}$ & $8.435 \pm 0.241^{* *}$ \\
\hline SD + Ginger & $4.770 \pm 0.214^{+++}$ & $7.184 \pm 0.217^{* *+++}$ \\
\hline Ginger & $4.172 \pm 0.250^{+++}$ & $5.396 \pm 0.169^{*+++}$ \\
\hline Recovery Sleep & $4.711 \pm 0.180^{+++}$ & $5.502 \pm 0.255^{*+++}$ \\
\hline
\end{tabular}

* Significant difference from control, * $(\mathrm{P}<0.05)$ Sign. ** $(\mathrm{P}<0.01)$ High sign.

*** Very high sign.

+ Significant difference from sleep deprived rats, $+(\mathrm{P}<0.05)$ Sign.

$++(\mathrm{P}<0.01)$ High sign. +++ Very high sign 
Table 7: Effect of Ginger and Recovery Sleep on Levels of Total IgGs, C- reactive Protein (CRP) and Erythrocytes Sedimentation Rate (ESR) in Blood of Sleep Deprived Rats

\begin{tabular}{|l|l|l|l|}
\hline Group & $\begin{array}{l}\text { Total IgGs } \\
(\mathrm{mg} / \mathrm{ml})\end{array}$ & $\begin{array}{l}\text { CRP } \\
(\mathrm{mg} / \mathrm{ml})\end{array}$ & $\begin{array}{l}\text { ESR } \\
(\mathrm{mm} / \mathrm{hr} 1)\end{array}$ \\
\hline Control & $4.016 \pm 0.135$ & $0.487 \pm 0.071$ & $3.000 \pm 0.258$ \\
\hline SD & $5.966 \pm 0.228^{* * *}$ & $0.538 \pm 0.054$ & $7.500 \pm 0.619^{* * *}$ \\
\hline SD + Ginger & $4.217 \pm 0.079^{+++}$ & $0.510 \pm 0.050$ & $4.833 \pm 0.307^{* *++++}$ \\
\hline Ginger & $3.999 \pm 0.148^{+++}$ & $0.495 \pm 0.044$ & $3.333 \pm 0.211^{+++}$ \\
\hline Recovery Sleep & $4.294 \pm 0.084^{+++}$ & $0.511 \pm 0.0374$ & $3.667 \pm 0.333^{+++}$ \\
\hline
\end{tabular}

* Significant difference from control, * $(\mathrm{P}<0.05)$ Sign. ** $(\mathrm{P}<0.01)$ High sign.

*** Very high sign.

+ Significant difference from sleep deprived rats, $+(\mathrm{P}<0.05)$ Sign. $++(\mathrm{P}<0.01)$ High sign.

+++ Very high sign

Table 8: Effect of Ginger and Recovery Sleep on Total and Differential Leukocytic Count in Sleep Deprived Rats

\begin{tabular}{|l|l|l|l|}
\hline \multicolumn{1}{|c|}{ Group } & Total Leukocyte & Lymphocytes & Neutrophiles \\
\hline Control & $7.373 \pm 0.354$ & $2.343 \pm 0.065$ & $4.230 \pm 0.080$ \\
\hline SD & $11.675 \pm 0.155^{* * *}$ & $2.713 \pm 0.085^{* *}$ & $6.299 \pm 0.133^{* * *}$ \\
\hline SD + Ginger & $7.967 \pm 0.564^{+++}$ & $2.871 \pm 0.012^{* * *}$ & $5.987 \pm 0.119^{* * *}$ \\
\hline Ginger & $5.920 \pm 0.174^{* *+++}$ & $2.319 \pm 0.053^{++}$ & $6.903 \pm 0.068^{* * *,++}$ \\
\hline Recovery sleep & $7.560 \pm 0.229^{+++}$ & $2.615 \pm 0.145^{*}$ & $6.341 \pm 0.212^{* * *}$ \\
\hline
\end{tabular}

* Significant difference from control, * $(\mathrm{P}<0.05)$ Sign. ** $(\mathrm{P}<0.01)$ High sign.

*** Very high sign.

+ Significant difference from sleep deprived rats, $+(\mathrm{P}<0.05)$ Sign. $++(\mathrm{P}<0.01)$ High sign.

+++ Very high sign

Table 9: Effect of Ginger and Recovery Sleep on Blood Brain Barrier Permeability of Sleep Deprived Rats

\begin{tabular}{|l|l|l|l|}
\hline \multicolumn{1}{|c|}{ Group } & $\begin{array}{l}\text { Cortex } \\
\text { (\% of Control) }\end{array}$ & $\begin{array}{l}\text { Midbrain } \\
\text { (\%of Control) }\end{array}$ & $\begin{array}{l}\text { Brain stem } \\
\text { (\% of Control) }\end{array}$ \\
\hline SD & $139.5 \pm 9.4^{*}$ & $168 \pm 14.5^{* *}$ & $151.9 \pm 10.5^{*}$ \\
\hline SD + Ginger & $119.7 \pm 8.3$ & $114.6 \pm 12.1^{+}$ & $119.1 \pm 13.4^{+}$ \\
\hline Ginger & $109.2 \pm 11.1^{+}$ & $105.7 \pm 12.0^{++}$ & $113.5 \pm 9.8^{++}$ \\
\hline Recovery sleep & $108.8 \pm 9.9^{+}$ & $106.4 \pm 8.4^{++}$ & $110.5 \pm 11.3^{++}$ \\
\hline
\end{tabular}

* Significant difference from control, * $(\mathrm{P}<0.05)$ Sign. ** $(\mathrm{P}<0.01)$ High sign.

*** Very high sign.

+ Significant difference from sleep deprived rats, $+(\mathrm{P}<0.05)$ Sign. $++(\mathrm{P}<0.01)$ High sign.

+++ Very high sign 


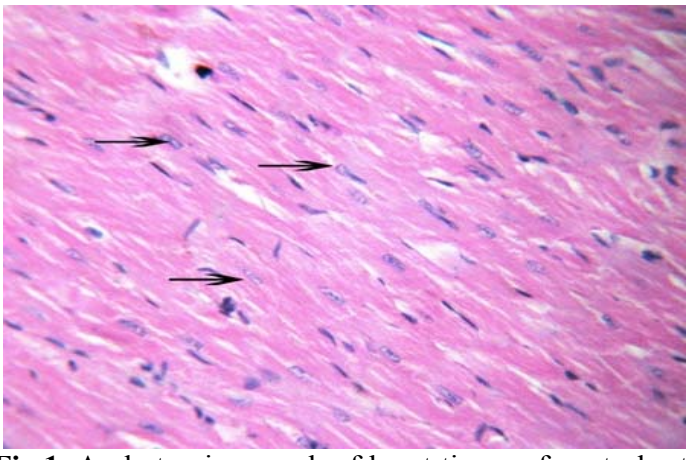

Fig.1. A photomicrograph of heart tissue of control rat, demonstrating branching and anastomsing cardiac muscles (Arrows). (H\&E, X:100).

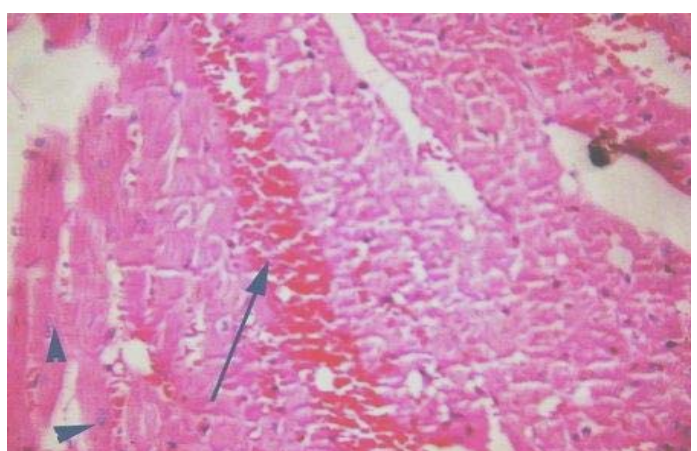

Fig.3. A photomicrograph of heart tissue of sleep deprived rat, showing hemorrhage areas between cardiac muscles (arrow) and dislocated nuclei (arrow head). (H\&E, X: 100).

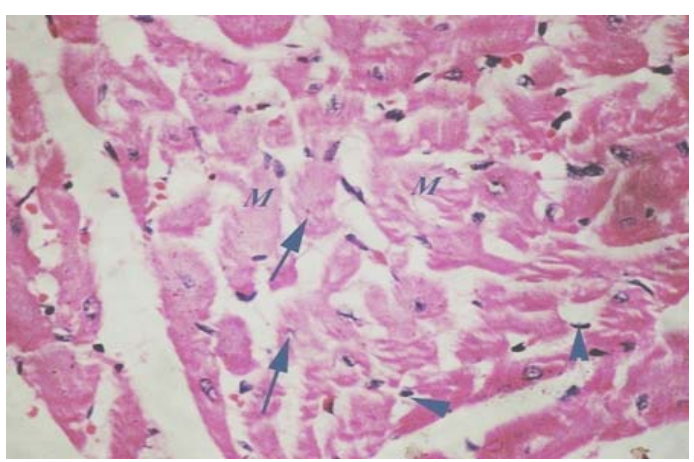

Fig.5. A photomicrograph of heart tissue of sleep deprived rat, demonstrating degenerated myofibrils (M), pyknotic nuclei (Arrow), inflammatory cells (arrow head).

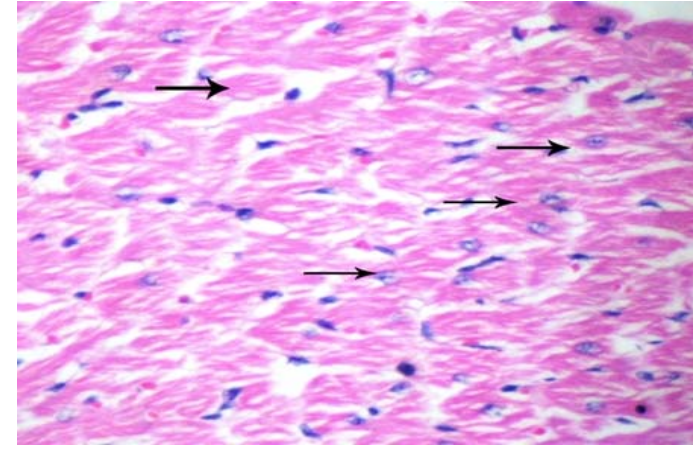

Fig.2. A photomicrograph of heart tissues of control rat, showing the transversely cut fibers having central vesicular nuclei (Arrows). (H\&E, X: 100).

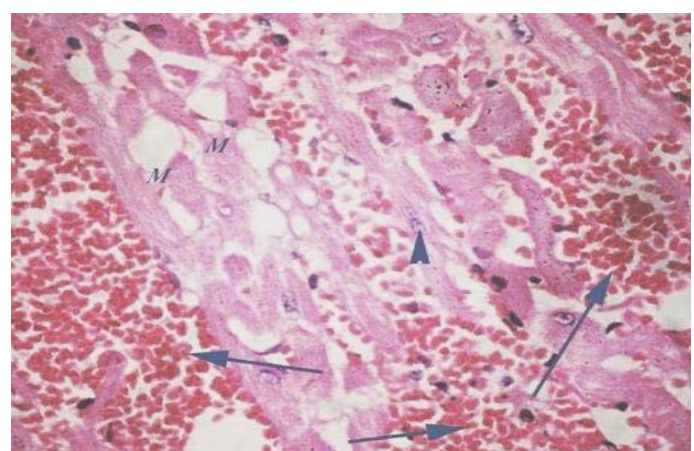

Fig.4. A photomicrograph of heart tissue of sleep deprived rat, showing extensive RBC's aggregates between myofibrils (arrow), faintly stained myofibrils (M) and dislocated nucleus (arrow head). (H\&E,X:200)

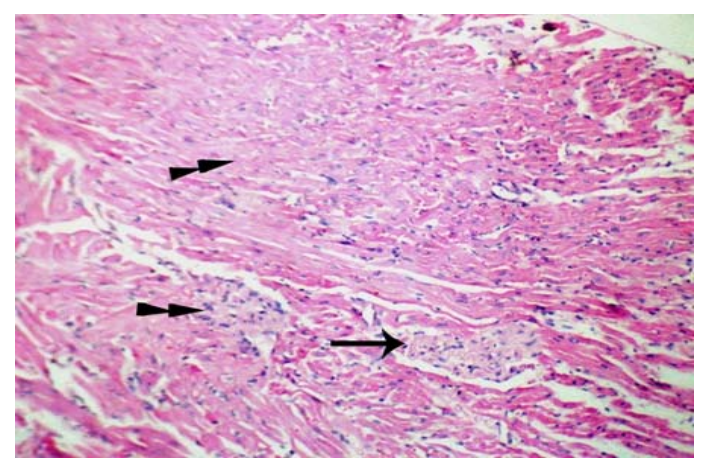

Fig.6. A photomicrograph of heart tissue of sleep deprived rat, showing multi focal areas of degenerated cardiomyocytes (Arrows), (H\&E,X:40) 


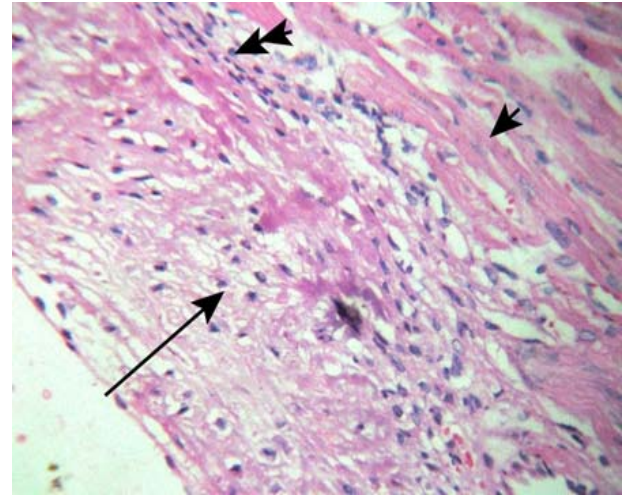

Fig.7. A photomicrograph of heart tissues of SD rat showing degenerated area (Arrow), inflammatory cells (double arrow) and cardiomyocyte with pyknotic nucleus (Short arrow) (H\&E, X: 200).

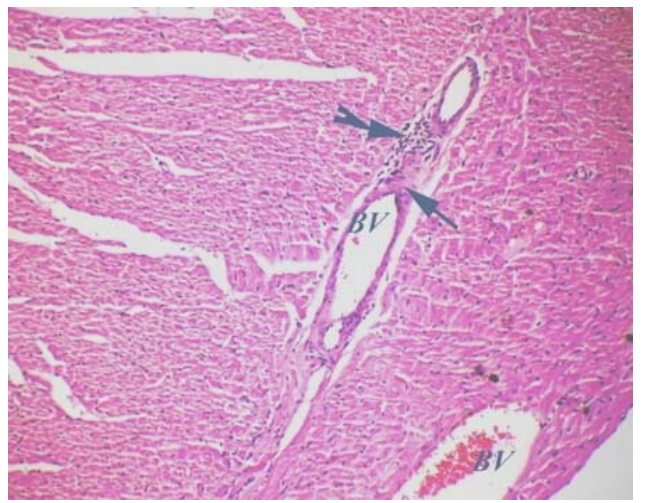

Fig.9. A photomicrograph of heart tissue of $\mathrm{SD}+$ ginger treated rat, demonstrating dilated blood vessels in between cardiac muscles (BV) and inflammatory cells (Double arrow) (H\&E, X: 40).

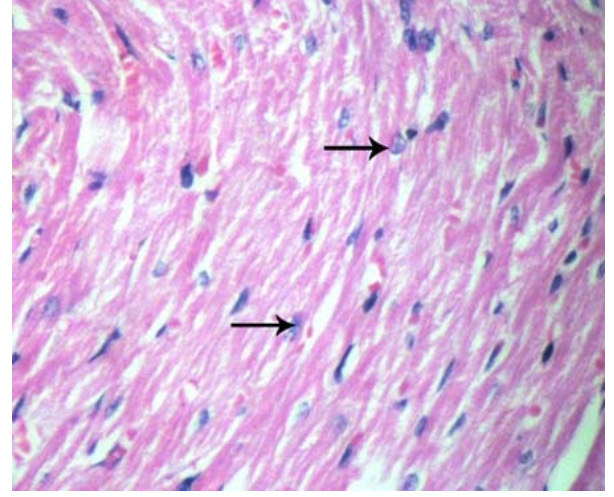

Fig.8. A photomicrograph of heart tissue of ginger treated rat, showing intact cardiomyocyte with vesicular nuclei (Arrows) (H\&E, X: 200).

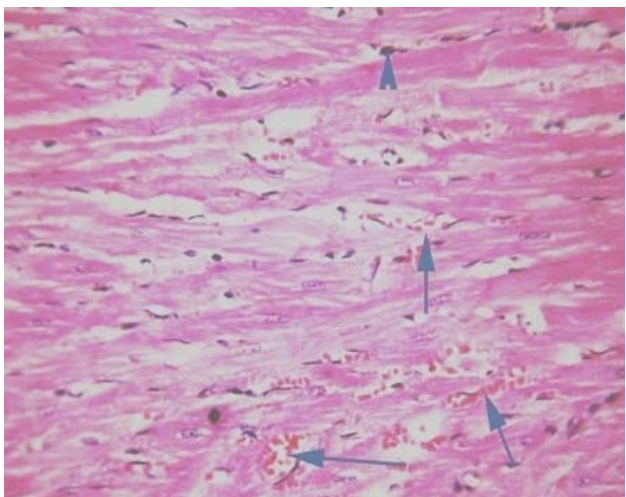

Fig.10. A photomicrograph of heart tissues of recovery sleep group, showing multiple dilated blood capillaries between cardiac muscle fibers (Arrows), (H\&E, X: 200).

\section{DISCUSSION}

In the present study, sleep deprivation reduced the total antioxidant activity, indicating the occurrence of oxidative stress and increased susceptibility to oxidative damage. The depressed levels of vitamin $\mathrm{C}$ and reduced glutathione with disturbed ratio of GSH/GSSG, beside the increased levels of MDA and protein carbonyls might support this claim. In accordance, several studies demonstrated that sleep deprivation for 72 hours induced oxidative damage and caused behavioral abnormalities in mice $\mathrm{e}^{(30-32)}$. In addition, sleep deprivation 
significantly inhibited the mitochondrial electron transport chain and energy metabolism ${ }^{(3)}$.

Moreover, sleep deprivation induced inflammatory reactions in terms of elevated total leucocytic count and elevated ESR, increased total IgGs, and did not affect CRP level. High erythrocyte sedimentation rate (ESR), likely due to an increase in globulins or fibrinogens levels, indicates a non-specific inflammation. Despite that a high level of CRP serves as a general indication of acute inflammation, in some inflammatory disease, such as rheumatoid arthritis and lupus, a low CRP level is possible, and is not indicative of no inflammation. In accordance to the present study, a previous study showed that sleep restriction to four hours for three consecutive nights increased white blood cells, mainly neutrophil count, in young healthy $\operatorname{men}^{(6)}$. Moreover, sleep deprivation for 24 hours increased the levels of total immunoglobulins in human ${ }^{(7)}$, and increased inflammatory markers of cardiovascular risk ${ }^{(8,9)}$. Ginger pretreatment significantly minimized the oxidative and inflammatory damage of sleep deprivation. This might be attributed to the antioxidant property of ginger. In accordance, several studies demonstrated the antioxidant and anti- inflammatory activities of ginger ${ }^{(19,}{ }^{32)}$. Moreover, recovery sleep considerably minimized the harmful effects of sleep deprivation. This might mirror the antioxidant effect of recovery sleep. In accordance, a recent study indicated that recovery sleep has a restorative effect on the body homeostasis ${ }^{\mathbf{1 2})}$.
Sleep deprivation compromised blood brain barrier integrity and caused extravasations of Evan's blue into brain tissues. One might speculate that there exists a link between inflammation and oxidative stress and the increase in barrier permeability. This can be interpreted that inflamed endothelium could secrete proinflammatory cytokines, accompanied with the activated macrophages which produce numerous factors that are injurious to the cerebrovascular endothelium. This, in turn, could lead to the increased permeability of the bloodbrain barrier ${ }^{(33)}$. Accordingly, it is likely that inadequate sleep might affect the functioning of the lining inside the blood vessels and can cause some low-grade inflammation that could lead to heart disease and increased blood brain barrier permeability. Moreover, the observation that recovery sleep considerably reversed the effect of sleep deprivation and restored the normal permeability might indicate that the effect of sleep deprivation is temporally and reversible. The protective effect of ginger treatment to blood brain barrier may be due to its antioxidant and anti-inflammatory properties

In addition, the present study showed that weakened antioxidant defense system and the inflammation resulted from sleep deprivation was enough to induce histological damage. It's worthy to note that sleep deprivation might mimic the body's neuroendocrine response to stressful circumstances. Consistently, administering the hormones normally released during stressful exposures 
also impairs sleep quality, affects immune function and disturbs sleep and waking rhythms ${ }^{(34)}$.

The observation that ginger caused significant amelioration in sleep deprivation-induced oxidative stress in plasma and heart of rats, as compared with those sleep deprivation group might indicate an antioxidant property of ginger. Ginger not only prevented the increase in free radical damage to lipids, but also greatly lessened depletion of reduced glutathione, one of the body's most important internally produced antioxidants. In addition, ginger prevented the histopathological abnormalities under sleep deprivation. In accordance, several studies indicated that ginger has antioxidant, anti-inflammatory, and antitumor activities ${ }^{(\mathbf{1 3}, 35,36)}$.

It's worthy to note that stress exposure leads to strong increases in the plasma levels of glucocorticoid stress hormones whereas in the present study plasma level of corticosterone after sleep deprived rats insignificantly increased in comparison to the control rats. In accordance, earlier studies have shown that severe sleep restriction does not lead to persistent increases in glucocorticoid levels ${ }^{(37)}$. In fact, undisturbed and spontaneously behaving rodents, for example, eating and grooming, show mild increases in plasma corticosterone levels. This might indicate that sleep adverse effect are not stress earnings of sleep deprivation.

In addition, it seems that there is a mutual correlation between inflammation and oxidative stress ${ }^{(38)}$. Moreover, it is likely that the mechanism of action that underlies ginger's anti-inflammatory effect is to suppress the pro-inflammatory compounds (cytokines and chemokines) produced by leukocytes (immune cells) and suppressing the release of free radicales.

In accordance to our result, a recent study indicated that aqueous extract of ginger along with paraben significantly ameliorated parabeninduced lipid peroxidation in the liver of mice ${ }^{(39)}$. Moreover, an in-vitro study showed that five diarylheptanoids (1-5) isolated from the roots of ginger ( $Z$. officinale) were capable of scavenging free radicals and inhibiting lipid peroxidation ${ }^{(\mathbf{4 0})}$. In addition, pretreatment with ginger extract prevented the hepatotoxic effect and oxidative and damage of bromobenzene in rats ${ }^{(41)}$.

The study indicated that sleep deprivation adverse effects are mediated, in part, through inflammatory reactions and oxidative stress. Ginger offered a protective effect through its antioxidant and antiinflammatory properties. Recovery sleep showed a restorative effect against sleep deprivation effects. In addition, recovery sleep represents the regenerative power of the body to regain the normal physiological homeostasis after the riddance of the external insult.

\section{Acknowledgements}

The author would like to thank Dr. Sahar Darwish and Dr. Mohamed El-Sharkawi for their technical assistance in the histopatholog and hematology investigations. 


\section{REFERENCES}

1. Andersen, M.L., Martins, P.J., Almeida, V.D., Bignotto, M. and Tufik, S. (2005): Endocrinological and catecholaminergic alterations during sleep deprivation and recovery in male rats. $J$ Sleep Res. 14:83-90.

2. Van Cauter, E., Spiegel, K., Tasali, E. and Leproult, R. (2008): Metabolic consequences of sleep and sleep loss. Sleep Med. 9: 23-28.

3. Andreazza, A.C., Andersen, M.L., Alvarenga, T.A., deOliveira, M.R., Armani, F., Ruiz, F.S., Giglio, L., Moreira, J.C., Kapczinski, F. and Tufik, S. (2010): Impairment of the mitochondrial electron transport chain due to sleep deprivation in mice. J Psychiatr Res. \{Epub ahead of print]

4. Rechtschaffen, A., Bergmann, B.M., Everson, C.A. and Gulliland, M.A. (2002): Sleep deprivation in the rat: $X$. Integration and discussion of the findings.1989. Sleep 25: 68-87.

5. Gopalakrishnan, A., Ji. L.L. and Cirelli, C. (2004): Sleep deprivation and cellular responses to oxidative stress. Sleep 27: 2735.

6. Boudjeltia, K.Z., Faraut, B., Stenuit, P., Esposito, M.J., Dyzma, M., Brohée, D., Ducobu, J., Vanhaeverbeek, M. and Kerkhofs, M. (2008): Sleep restriction increases white blood cells, mainly neutrophil count, in young healthy men: a pilot study.
Vasc Health Risk Manag. 4: 1467-1470.

7. Hui, L., Hua, F., Diandong, $H$. and Hong, Y. (2007): Effects of sleep and sleep deprivation on immunoglobulins and complement in humans. Brain Behav Immun. 21: 308-310.

8. Meier-Ewert, H.K., Ridker, P.M., Rifai, N., Regan, M.M., Price, N.J., Dinges, D.F. and Mullington, J.M. (2004): Effect of sleep loss on C-reactive protein, an inflammatory marker of cardiovascular risk. Am Coll Cardiol. 43: 678-683.

9. Kokturk, O., Ciftci, T.U., Mollarecep, E. and Ciftci, B. (2005): Elevated C-reactive protein levels and increased cardiovascular risk in patients with obstructive sleep apnea syndrome. Int Heart J.46: 801809.

10. Ye, J., Liu, H., Li, Y., Liu, X. and Zhu, J.M. (2007): Increased serum levels of C-reactive protein and matrix metalloproteinase- 9 in obstructive sleep apnea syndrome. Chin Med J (Engl), 120: 1482-1486.

11. Ladewig, G., Jestaedt, L., Misselwitz, B., Solymosi, L., Toyka, K., Bendszus, M. and Stoll, G.(2009): Spatial diversity of blood-brain barrier alteration and macrophage invasion in experimental autoimmune encephalomyelitis: a comparative MRI study. Exp Neurol. 220: 207-211.

12. Ikegami, K., Ogyu, S., Arakomo, Y., Shirakawa, C., Suzuki, K., Tahara, H., Moriyama, K., Mafune, K., 
Hiro, H., Nagata, S. and Kasai, H. (2010): Urinary 8hydroxydeoxyguanosine levels and psychological reactions after sleep deprivation. J UOEH. 32(1):1-10.

13. Ajith, T.A., Aswathy, M.S., and Hema, U. (2008): Protective effect of Zingiber officinale roscoe against anticancer drug doxorubicin-induced acute nephrotoxicity. Food Chem Toxicol. 46:3178-3181.

14. Sang, S., Hong, J., Wu, H., Liu, J., Yang, C.S., Pan, M.H., Badmaev, V. and Ho, C.T. (2009): Increased growth inhibitory effects on human cancer cells and antiinflammatory potency of shogaols from Zingiber officinale relative to gingerols. $J$ Agric Food Chem. 57: 10645-10650.

15. Grzanna, R., Lindmark, L. and Frondoza, C.G. (2005): Gingeran herbal medicinal product with broad anti-inflammatory actions. J Med Food, 8(2): 125-32

16. Ojewole, J.A. (2006): Analgesic, antiinflammatory and hypoglycaemic effects of ethanol extract of Zingiber officinale (Roscoe) rhizomes (Zingiberaceae) in mice and rats. Phytother Res. 20: 764-772.

17. Chrubasik, J.E., Roufogalis, B.D. and Chrubasik, S. (2007): Evidence of effectiveness of herbal anti-inflammatory drugs in the treatment of painful osteoarthritis and chronic low back pain. Phytother Res. 21: 675-683.

18. Ahui, M.L., Champy, P., Ramadan, A., Pham, Van, L.,
Araujo, L., Brou André, K., Diem, S., Damotte, D., KatiCoulibaly, S., Offoumou, M.A., Dy, M., Thieblemont, N. and Herbelin A. (2008): Ginger prevents Th2-mediated immune responses in a mouse model of airway inflammation. Int Immunopharmacol. 8:1626-1632

19. Shati, A.A. and Elsaid, F.G. (2009): Effects of water extracts of thyme (Thymus vulgaris) and ginger (Zingiber officinale Roscoe) on alcohol abuse. Food Chem Toxicol. 47: 1945-1949.

20. Shinomiya, K., Shigemoto, Y., Okuma, C., Mio, M. and Kamei, C. (2003): Effects of short- acting hypnotics on sleep latency in rats placed on grid suspended over water. Eur J Pharmacol. 460: 139-144.

21. Ahrer, K., Buchacher, A., Iberer, G., Josic, D. and Jungbauer, A. (2003): Analysis of Aggregates of human immunoglobulin $G$ using sizeexclusion chromatography, static and dynamic light scattering. $J$ chromatogr A. 1009 (1-2): 89-96

22. Jayatilleke, E. and Shaw, S. (1993): A high-performance liquid chromatographic assay for reduced and oxidized glutathione in biological samples. Analytical Biochemistry 214(2), 452-457

23. Or-Rashid, M.M., Onodera, R., Wadud, S. and Mohammed, N. (2000): Convenient method of threonine, methionine and their related amino compounds by high-performance liquid chromatography and its application to rumen fluid. Journal of Chromatography $B$ 
Biomedical Sciences \& Applications 741(2), 279-287

24. Karatepe M (2004): Simultaneous determination of ascorbic acid and free malondialdehyde in Human Serum by HPLC-UV. Liquid Chromatography \& Gas Chromatography North America 22,362-365

25. Adams, S., Green, P., Claxton, R., Simcox, S., Williams, M.V., Walsh, K. and Leeuwenburgh, C. (2001): Reactive carbonyl formation by oxidative and nonoxidative pathways. Frontiers in Biosci. 9: a 17-24.

26. Lowry, O.H., Rose brough, N.J., Farr, A.L. and Randall, R.J. (1951): Protein measurement with the Folin phenol reagent. $J$ Biol Chem., 193: 265-275.

27. Simmons, A. and Bernard, E.S. (1997): Hematology (Combined Theoretical and Technical Approach). Butterworth Heinemann, 255-281.

28. Carleton, H.H. and Drury, R.A. (1973): Histological technique for normal and pathological tissues and the identification of parasites. Oxford University Press, London, (fifth edition).

29. Mikawa, S., Kinouchi, H., Kamii, H., Gobbell, G.T., Chen, S.F., Carlson, E., Epstein, C.J. and Chan, P.H. (1996): Attenuation of acute and chronic damage following traumatic brain injury in copper, zinc-super oxide dismutase transgenic mice. $J$ Neurosurg 85:885-891.

30. Kumar, A. and Garg, R. (2009): Possible role of trazodone and imipramine in sleep deprivationinduced anxiety-like behavior and oxidative damage in mice. Methods Find Exp Clin Pharmacol. 31: 383-387.

31. Dugasani, S., Pichika, M.R., Nadarajah, V.D., Balijepalli, M.K., Tandra, S. and Korlakunta, J.N. (2010): Comparative antioxidant and anti-inflammatory effects of [6]gingerol, [8]-gingerol, [10]gingerol and [6]-shogaol. $J$ Ethnopharmacol. 127: 515-520.

32. Kumar, A. and Singh, A. (2009): Possible involvement of GABAergic mechanism in protective effect of melatonin against sleep deprivation-induced behaviour modification and oxidative damage in mice. Fundam Clin Pharmacol. 23: 439-448.

33. Nanjundaiah, S.M., Annaiah, H.N.M. and Dharmesh, S. (2009): Gastroprotective Effect of Ginger Rhizome (Zingiber officinale) Extract: Role of Gallic Acid and Cinnamic Acid in $\mathrm{H}+$, $\mathrm{K}+$-ATPase/H. pylori Inhibition and Anti-oxidative Mechanism. Evid Based Complement Alternat Med. [Epub ahead of print].

34. Simka, M. (2009): Blood brain barrier compromise with endothelial inflammation may lead to autoimmune loss of myelin during multiple sclerosis. Curr Neurovasc Res. 6(2):132-9.

35. Fossey, M., Libman, E., Bailes, S., Baltzan, M., Schondorf, R., Amsel, R. and Fichten, C.S. (2004): Sleep quality and psychological adjustment in CFS. J Behav Med 27:581-605. 
36. Zhang, G.F., Yang, Z.B., Wang, Y., Yang, W.R., Jiang, S.Z. and Gai, G.S. (2009): Effects of ginger root (Zingiber officinale) processed to different particle sizes on growth performance, antioxidant status, and serum metabolites of broiler chickens. Poult Sci. 88: 2159-2166.

37. Roman, V., Walstra, I., Luiten, P.G. and Meerlo P. (2005): Too little sleep gradually desensitizes the serotonin $1 \mathrm{~A}$ receptor system. Sleep 28:1505-1510.

38. Novoselova, E.G., Lunin, S.M., Novoselova, T.V., Khrenov, M.O., Glushkova, O.V., Avkhacheva, N.V., Safronova, V.G. and Fesenko, E.E. (2009): Naturally occurring antioxidant nutrients reduce inflammatory response in mice. Eur $J$ Pharmacol. 615: 234-240.
39. Asnani, V.M. and Verma, R.J. (2009): Ameliorative effects of ginger extract on parabeninduced lipid peroxidation in the liver of mice. Acta Pol Pharm. 66: 225-228

40. Yang, L., Zhou, C., Huang, K., Song, L., Zheng, Q., Yu, R., Zhang, R., Wu, Y., Zeng, S., Cheng, C.H., Zhao, Y., Li, X. and Qu, J. (2009): Antioxidative and cytotoxic properties of diarylheptanoids isolated from Zingiber officinale. Zhongguo Zhong Yao Za Zhi. 34: 319-323

41. El-Sharaky, A.S., Newairy, A.A., Kamel, M.A. and Eweda, S.M. (2009): Protective effect of ginger extract against bromobenzene-induced hepatotoxicity in male rats. Food Chem Toxicol. 47: 1584-1590. 


\section{يقلل الجنزبيل من التأثيرات الضارة للحرمان من النوم.

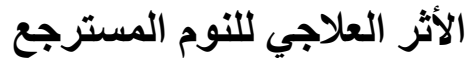 \\ أحدل محدل شحاتة \\ قسم الفسيولوجي- الهيئة القومية للرقابة و البحوث الدو ائية}

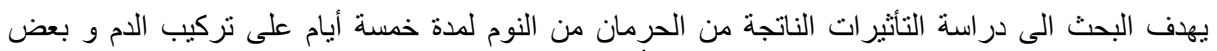

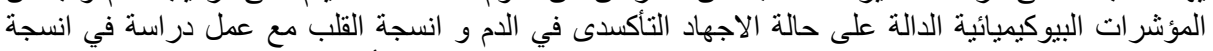

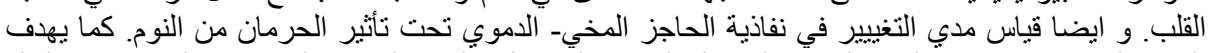

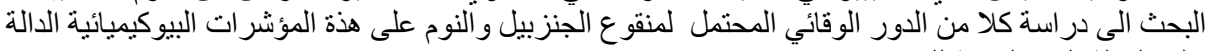

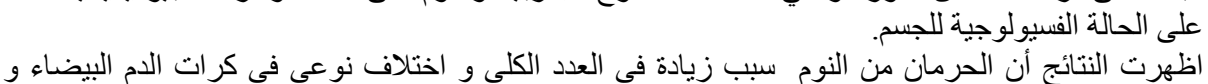

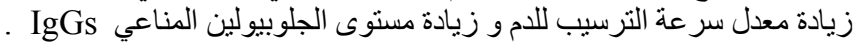

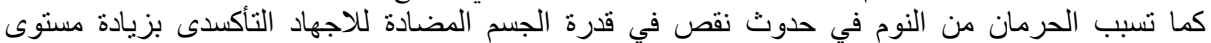

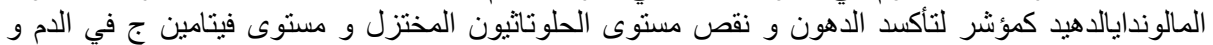

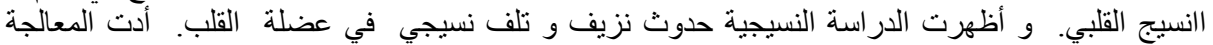

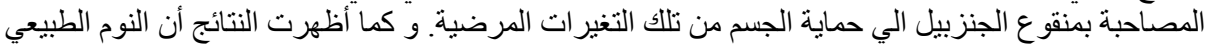

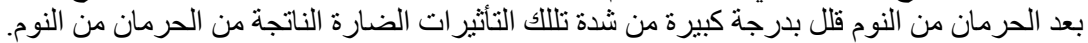

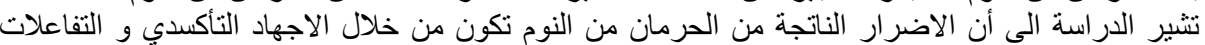

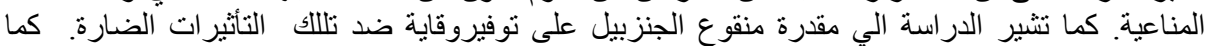

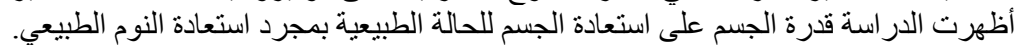

